\title{
Histological localization of plasminogen activator and proteolytic activity in the human stomach and duodenum
}

\author{
P. ERAS, P. HARPEL, AND S. J. WINAWER \\ From the Department of Medicine, The New York Hospital, Cornell Medical Center, and the Memorial \\ Hospital for Cancer and Allied Diseases, New York
}

SUMMARY Plasminogen activator activity has been localized in gastric and duodenal tissue using a histological technique. This activity could be separated from proteolytic activity by incorporating $\epsilon$-aminocaproic acid into the fibrin substrate or by heat treatment. Plasminogen activator activity was found in relation to mucosal and submucosal blood vessels in the tissues studied. Proteolytic activity was identified in the surface epithelium, the gastric antral and fundal glands, and in the antral submucosal fat. Proximal duodenal tissue contained proteolytic activity in relation to Brunner's glands.

Fibrinolytic activator activity (plasminogen activator) has been found in extracts of gastric and duodenal mucosa from patients with duodenal ulcer disease (Cox, Poller, and Thompson, 1967). The present study reports on the histological localization of this activity in human gastric and duodenal tissue. Proteolytic activity could also be localized and distinguished from plasminogen activator activity. This was accomplished by the use of $\epsilon$-aminocaproic acid and heat treatment of the fibrin substrate (Fig. 1).

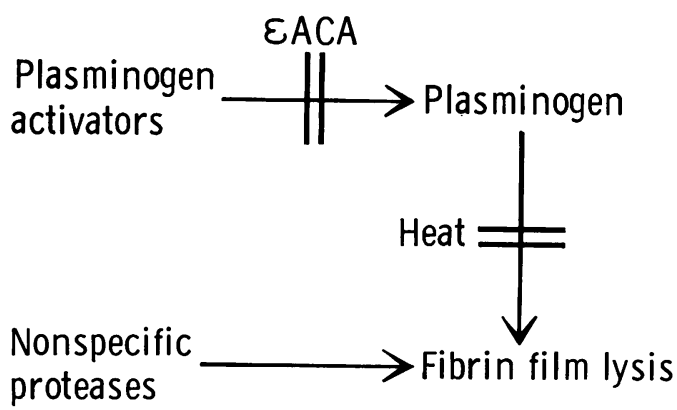

Fig. 1. Outline of the pathway by which 6-aminocaproic acid ( $\epsilon-A C A)$ and heat treatment of the fibrin film substrate distinguish plasminogen activator from non-specific proteolytic activity.

\section{Patients and Methods}

Tissue from the body of the stomach was obtained at surgery from three patients operated on for duodenal ulcer disease. In one patient, additional specimens were obtained from the gastric fundus, antrum, and duodenum. These specimens were taken from areas which appeared grossly normal. Microscopic examination of haematoxylin and eosin-stained sections of these tissues showed a normal appearance without evidence of inflammation. Surgical specimens half an inch square were washed in $0.15 \mathrm{M}$ sodium chloride and were quick-frozen in an International-Harris cryostat microtome, and then stored at $-25^{\circ} \mathrm{C}$ and assayed within three weeks.

Plasminogen-rich fibrinogen was prepared from citrated bovine plasma according to the method of Kekwick, MacKay, Nance, and Record (1955). The Kekwick F. 1 W low-ionic strength, coldinsoluble fibrinogen fraction was reconstituted in citrate-saline buffer at a concentration of $3.0 \mathrm{~g} \%$ and stored at $-20^{\circ} \mathrm{C}$ for use in preparing fibrin films.

FIBRIN FILMS

Twenty NIH units of bovine thrombin (ParkeReseived for publication 9 March 1970. 
Davis Co.) were added to $10 \mathrm{ml}$ bovine fibrinogen which was then diluted in Michaelis veronal buf-

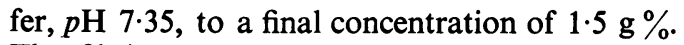
The fibrinogen was allowed to clot on a level cellophane strip $8 \times 17 \mathrm{~cm}$ in a humid chamber at $4^{\circ} \mathrm{C}$. Squares of fibrin clot, each $2 \mathrm{~cm}$, on cellophane were cut and inverted (fibrin face down) on a glass slide and the cellophane was removed. Tissue sections from each specimen were then cut 8 microns thick on the cryostat, placed on fibrin films and the fibrin slides were incubated at $37^{\circ} \mathrm{C}$ in a moist chamber for $0,1,3,5$, $10,30,45$, and 60 minutes. The reaction was stopped by immersion in $10 \%$ formaline-saline for five minutes. The fibrin film was stained with a modification of the haematoxylin and eosin stain. Excess fibrin was trimmed with a sharp knife, and the preparation covered with permount and a coverslip. The prepared slides were viewed with a stereoscopic microscope to determine the presence of depressed colourless areas in the fibrin film which represented areas of fibrin digestion. The shortest incubation time required to produce a clearly visible zone of lysis was noted and served as a semi-quantitative index of fibrinolytic activity.

\section{PLASMINOGEN-FREE FIBRIN FILMS}

Fibrin films were prepared in the manner described, following which they were heated at $85^{\circ} \mathrm{C}$ for 30 minutes in a moist chamber to destroy fibrin-associated plasminogen (Lassen, 1952).

\section{E-AMINOCAPROIC ACID-CONTAINING FIBRIN FILMS}

Fibrin films were prepared as described with $1 \times 10^{-3} \mathrm{M}$ e-aminocaproic acid added to the fibrinogen solution to inhibit selectively fibrinolysis produced by plasminogen activator activity (Alkjaersig, Fletcher, and Sherry, 1959).

\section{Results}

The gastric and duodenal surface epithelium showed proteolytic activity which was not inhibited by $\epsilon$-aminocaproic acid or by heat treatment of the fibrin substrate. The data on location of fibrinolytic activity in the tissues 9 studied (other than surface epithelial activity), the earliest time of onset of lysis, and the effect of adding $\epsilon$-aminocaproic acid and heating the fibrin substrates are summarized in the Table.등 The gastric fundus showed proteolytic activity in $\overline{\bar{c}}$. the surface epithelium and glands. Plasminogen $\vec{\sigma}_{\vec{\sigma}}$ activator activity was found in mucosal and sub- $\varrho$ mucosal blood vessels (Fig. 2). Similar findingses were present in the gastric antrum. In sections $\overrightarrow{0}$ taken from the transitional zone, the antralglands showed greater non-inhibitable proteolytic. activity than did the fundal glands (Fig. 3). Ino addition, the antral submucosal fat caused lysis $\rightleftharpoons$ of the fibrin films which was not inhibited by $\epsilon$-aminocaproic acid or by heat treatment. The $\vec{\circ}$ proximal duodenum showed proteolytic activity oo in the surface epithelium, crypts, and Brunner's $\mathcal{G}$ glands. Activity of plasminogen activator was음 localized to the mucosal and submucosal blood vessels (Fig. 4).

\section{Discussion}

Fibrinolytic activity of tissue may be caused either by proteases which can directly hydrolyse fibrin or by tissue activators which convert plasminogen to plasmin, the fibrinolytic enzyme. Albrechtsen (1959) found that most tissue con- $\unrhd$ tained plasminogen activator, but he did not $\overrightarrow{\vec{O}}$ examine gastrointestinal tissue. Histological techniques, developed by Todd (1959 and 1964), made it possible to examine plasminogen-activator activity of tissue in relation to histological $\stackrel{0}{0}$ structure. His studies and those of others showed that the activity of plasminogen activator is mainly associated with the blood vessels of the various tissues examined (Kwaan, 1966).

Studies of fibrinolytic activity in the gastrointestinal tract are few. Kwaan, Cocco, and Mendeloff (1964) have shown activity of plasminogen activator at sites of crypt abscesses in patients with active ulcerative colitis. Cox et al సু (1967) found fibrinolytic activity in gastric vein $N$ blood and no activity in samples obtained from the gastric artery. Saline extracts of the gastric and duodenal mucosa contained plasminogen

\begin{tabular}{|c|c|c|c|c|}
\hline \multirow[t]{2}{*}{ Patient } & \multirow[t]{2}{*}{ Tissue } & \multicolumn{3}{|c|}{ Histological Location and Time of Earliest Lysis } \\
\hline & & Fibrin & €-Aminocaproic Acid Fibrin & Heated Fibrin \\
\hline 1 & Gastric fundus & $\begin{array}{l}\text { Mucosal and submucosal blood } \\
\text { vessels ( } 20 \mathrm{~min})\end{array}$ & No lysis $(60 \mathrm{~min})$ & No lysis $(60 \mathrm{~min})$ \\
\hline 2 & Gastric fundus & $\begin{array}{l}\text { Mucosal and submucosal blood } \\
\text { vessels (15 min) }\end{array}$ & No lysis $(60 \mathrm{~min})$ & No lysis $(60 \mathrm{~min})$ \\
\hline \multirow[t]{3}{*}{3} & Gastric fundus & $\begin{array}{l}\text { Mucosal and submucosal blood } \\
\text { vessels }(10 \mathrm{~min})\end{array}$ & No lysis $(60 \mathrm{~min})$ & No lysis (60 min) \\
\hline & Gastric antrum & $\begin{array}{l}\text { Mucosal and submucosal blood } \\
\text { vessels, submucosal fat ( } 10 \mathrm{~min})\end{array}$ & $\begin{array}{l}\text { No lysis in blood vessels at } 60 \\
\text { min; fat cells active }\end{array}$ & $\begin{array}{l}\text { No lysis in blood vessels at } 60 \\
\text { min; fat cells active }\end{array}$ \\
\hline & Duodenum & $\begin{array}{l}\text { Mucosal and submucosal blood } \\
\text { vessels, Brunner's glands ( } 5 \text { min) }\end{array}$ & $\begin{array}{l}\text { No lysis in blood vessels at } 30 \\
\text { min; Brunner's glands active }\end{array}$ & $\begin{array}{l}\text { No lysis in blood vessels at } 30 \\
\text { min; Brunner's glands active }\end{array}$ \\
\hline
\end{tabular}




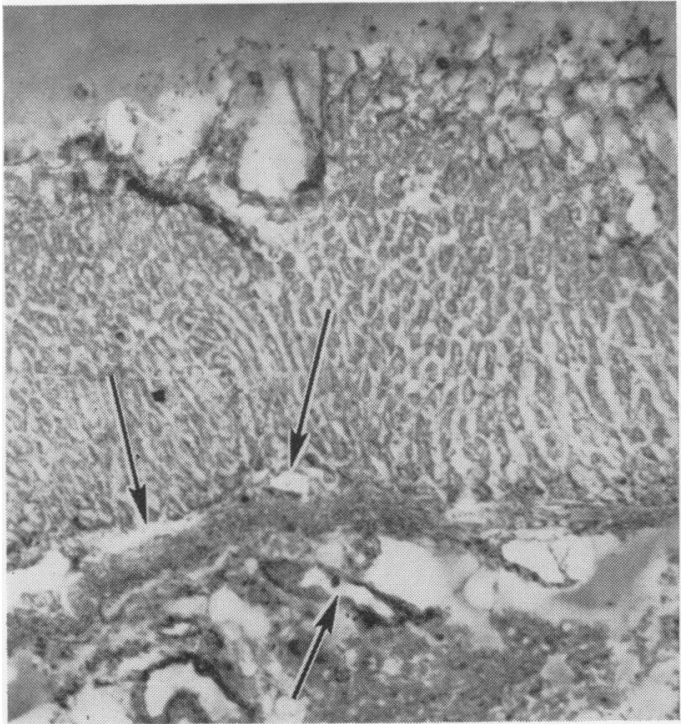

Fig. 2. Specimen from gastric fundus following 15-minute incubation with fibrin film (patient 2). Representative lytic zones, indicated by arrows, appear as light, unstained areas in relation to mucosal and submucosal blood vessels.

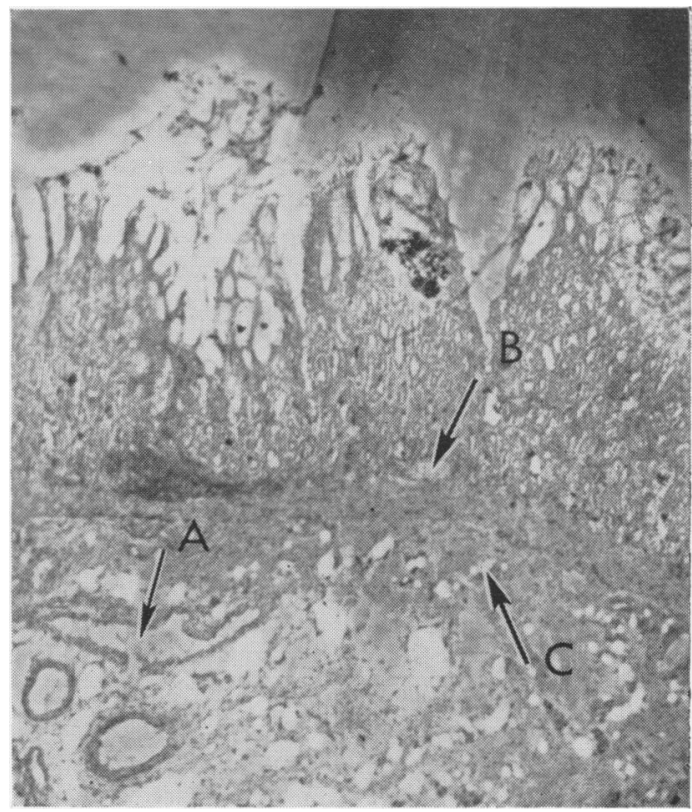

Fig. 3. Section of body of the stomach (patient 3) at transition zone of fundal and antral gland incubated 60 minutes with $\epsilon-A C A$ fibrin film. The clear lytic zones in relation to mucosal and submucosal blood vessels shown in Fig. 2 are now not present (arrows $A$ and $B$ ) indicating that the lysis was produced by plasminogen activator. Lytic zones are seen in relationship to submucosal fat cells (arrow C) indicating proteolytic activity. Antral glands on left show greater proteolytic activity than do fundal glands on right.

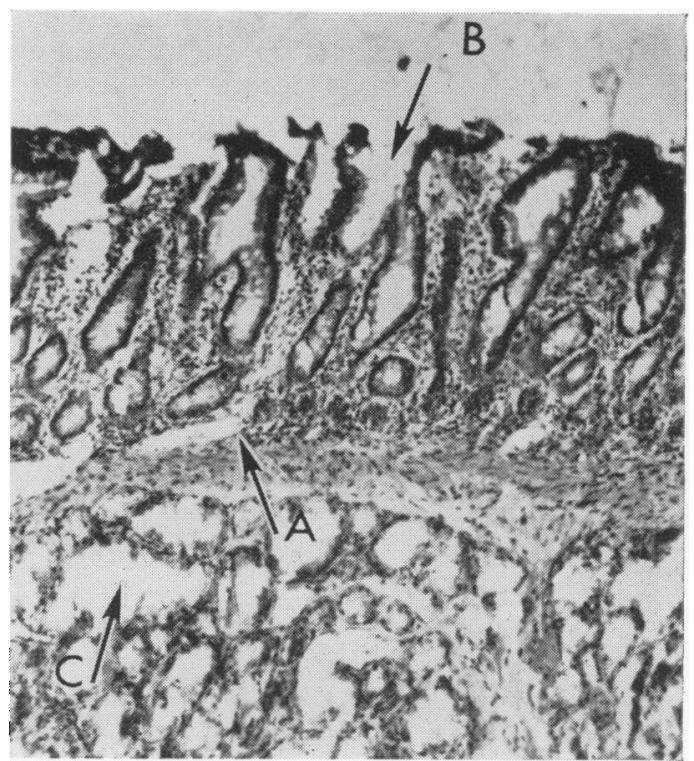

Fig. 4. Lytic zones in relationship to mucosal blood vessels $(A)$ in the proximal duodenum (patient 3 ) after five minutes' incubation. Proteolytic activity, not inhibited on heated or $\epsilon-A C A$ fibrin films, is associated with surface $(B)$ and Brunner's glands $(C)(\times 100)$. activator activity as shown by the ability to lyse plasminogen-rich fibrin plates but not to lyse heated or $\epsilon$-aminocaproic acid-containing plates. Cox, Poller, and Thomson (1969) have also found that digital gastric compression at laparotomy resulted in the development of plasmin-like activity in peripheral venous and in gastric venous blood. The highest fibrinolytic activity was found in patients with peptic ulcers.

The present study demonstrates that both plasminogen activator activity and proteolytic activity can be identified in human gastric and duodenal tissue by a histochemical technique. Although the tissues obtained were from patients undergoing surgery for duodenal ulcer disease no attempt can be made in this preliminary study to correlate the enzymatic findings with the presence of duodenal ulcer disease. In the specimens examined, plasminogen activator activity was found in superficial mucosal and submucosal blood vessels in the stomach and duodenum. That this is plasminogen activator was shown by the inhibition of this fibrinolytic activity by using a heated fibrin substrate or one containing $\epsilon$-aminocaproic acid in a concentration which would inhibit plasminogen activator but not plasmin itself or other proteases (Alkjaersig et al, 1959). In the specimen in which comparison 
was possible, there appeared to be more plasminogen activator activity associated with the vessels of the fundus than with the antrum.

Epithelial proteolytic activity, which was not inhibited by $\epsilon$-aminocaproic acid or heat treatment of the fibrin film, may be due to residual acid-pepsin. Pepsin in the presence of hydrochloric acid has been shown to cause fibrin plate lysis (Cox et al, 1967). In the present study, gastric tissue was washed extensively before assay in physiological saline, a procedure which might be expected to eliminate most $\mathrm{HCl}$ and surface pepsin. The assay was performed at neutral $p \mathrm{H}$, conditions which would favour the inactivation of both pepsin and peptic enzymes. The epithelial surface proteolytic activity observed might therefore be due to proteolytic enzymes active in the neutral $p \mathrm{H}$ range. Taylor (1959) has identified a protease in gastric mucosal tissue which is active at neutral $p \mathrm{H}$. The mucosal cells responsible for the production of this enzymatic activity have not been identified. It was of interest to find proteolytic activity associated with both the fundal and antral glands. Proteolytic activity was associated with the fundal, antral, and the Brunner's glands of the duodenum. The activity of the Brunner's and antral glands was greater than was the activity of the fundal glands. The production of pepsin occurs principally in the chief cells of the fundal glands. Small amounts of peptic-like activity have been reported in duodenal juice and duodenal mucosal extracts (Seijffers, Miller, and Segal, 1963; Cooke and Grossman, 1966) and in extracts from the pyloric gland area of the stomach (Grossman and Marks, 1960). Linderstrøm-Lang, Holtzer, and Ohlsen (1935) found acid protease activity of the gastric mucosa in the pig. Whereas highest activity correlated with peptic cells of the fundic glands, activity was found in mucosal cells of the pyloric and antral glands as well. In the present assay system the glands with the greatest proteolytic activity have been reported to have low levels of peptic activity. The activity observed may therefore be due to other as yet unidentified proteolytic enzymes.

Fat cells in the submucosa of the antrum also have proteolytic activity. To our knowledge, proteolytic activity associated with fat-containing cells has not been reported previously.

The presence of plasminogen activator activity and proteolytic activity in the stomach and duodenum could have implications in gastric and duodenal haemorrhage associated with variety of disease states.

This work was supported by a US Public Healttie Service traineeship CST 562A67 from the Cance Control Program; a US Public Health Service special fellowship 2-F3-CA-3A, 497-02, from the NIH, National Cancer Institute; by NIHP grant NB-0334605 (National Institute of Neurological Diseases and Blindness), and by an American Cancer Society research scholaf award.

\section{References}

Albrechtsen, O. K. (1959). Fibrinolytic activity in the organism? Acta physiol. scand., 47, Suppl. 165, 1-112.

Alkjaersig, N., Fletcher, A. P., and Sherry, S. (1959). є-Amino caproic acid: an inhibitor of plasminogen activation? J. biol. Chem., 234, 832-837.

Cooke, A. R., and Grossman, M. I. (1966). Studies on the secretion and motility of Brunner's gland pouches. Gastroenterology, 51, 506-514.

Cox, H. T., Poller, L., and Thomson, J. M. (1967). Gastric fibrinolysis. A possible aetiological link with peptic ulcer Lancet, 1, 1300-1302.

Cox, H. T., Poller, L., and Thomson, J. M. (1969). Evidence fo the release of gastric fibrinolytic activity into periphera blood. Gut, 10, 404-407.

Grossman, M. I., and Marks, I. N. (1960). Secretion of pepsinogem by the pyloric glands of the dog, with some observation? on the histology of the gastric mucosa. Gastroenterology 38, 343-352.

Kekwick, R. A., MacKay, M. E., Nance, M. H., and Record $\overrightarrow{\vec{D}}$ B. R. (1955). The purification of human fibrinogen 3 Biochem. J., 60, 671-683.

Kwaan, H. C. (1966). Tissue fibrinolytic activity studied by histochemical method. Fed. Proc., 25, 52-56.

Kwaan, H. C., Cocco, A., and Mendeloff, A. I. (1964). Histologico demonstration of plasminogen activation in rectal biopsies from patients with active ulcerative colitis. J. Lab. clin Med., 64, 877.

Lassen, M. (1952). Heat denaturation of plasminogen in thefibrin plate method. Acta physiol. scand., 27, 371-376.

Linderstrøm-Lang, K., Holtzer, H., and Ohlsen, A. S. (1935)윽 Studies on enzymatic histochemistry. XIII. The distribution of enzymes in the stomach of pigs as a function of its histologic structure. C.R. Lab. Carlsberg, Sér physiol., 20, 66-127.

Seijffers, M. J., Segal, H. L., and Miller, L. L. (1963). Separation of pepsin I, pepsin IIA and pepsin IIB, III from human gastric mucosa. Amer. J. Physiol., 205, 1099-1105

Taylor, W. H. (1959). Studies on gastric proteolysis. 4. Proteinase activity of gastric juice and gastric mucosal extracts at pH 6 to 8. Biochem. J., 71, 626-632.

Todd, A. S. (1959). The histological localization of fibrinolysin activator. J. Path. Bact., 78, 281-283.

Todd, A. S. (1964). Localization of fibrinolytic activity in tissues Brit. med. Bull., 20, 210-212. 